\title{
OBSERVATIONS ON THE ALTERATIONS IN ELECTROLYTES AND FLUID BALANCE IN PATIENTS WITH CIRRHOSIS OF THE LIVER WITH AND WITHOUT ASCITES
}

\author{
By WILLIAM E. RICKETTS, LILLIAN EICHELBERGER, AND \\ JOSEPH B. KIRSNER \\ (From Frank Billings Medical Clinic, Department of Medicine, University of Chicago, \\ Chicago, Ill.)
}

(Submitted for publication December 1, 1950; accepted August 6, 1951)

The mechanisms involved in the formation of edema and ascites in cirrhosis remain unclear. A variety of factors have been implicated including hypertension of the portal venous system, elaboration of anti-diuretic substances, decrease in the plasma albumin with concomitant reduction in the colloid osmotic pressure of the blood, and disturbances in electrolyte excretion. A study of the alteration of electrolytes in cirrhosis of the liver was undertaken in our laboratory early in 1948 and extended through 1949. Important contributions on this problem have appeared concurrently in the literature. Farnsworth and Krakusin (1) reported inadequate elimination of sodium chloride in the urine of two patients with portal cirrhosis and ascites, an observation recorded independently by Faloon and associates (2) and Eisenmenger and co-workers (3). Recently, Goodyer and colleagues (4), measuring mannitol and para-aminohippurate clearances, have suggested that the deficient excretion of salt in the urine is attributable to increased tubular reabsorption of sodium.

\section{METHODS}

Chemical methods. The following determinations were made simultaneously from serum and ascitic fluid (the latter obtained through a syringe needle): sodium by a modified Butler-Tuthill method $(5,6)$; potassium by a modified Shohl-Bennett method $(7,6)$; and chlorides by the Wilson and Ball (8) modification of the Van Slyke method (9). Measurements were also made of the following: non-protein nitrogen, plasma proteins and globulin fractions by the micro-Kjeldahl analysis, utilizing the separation method of Campbell and Hanna (10); serum $\mathrm{CO}_{2}$ (11), pH (12), and bromsulfalein test (13); hematocrit by the Wintrobe method (14); and plasma volume with Evans Blue by the method of Gibson and Evans (15).

The daily excretion of water, sodium, chloride, and potassium was measured under two dietary conditions, utilizing the same methods as for serum and ascitic fluid, except that a Beckman flame photometer was used for sodium and potassium.
Diets. Each patient was studied in the metabolism unit of Albert Merritt Billings Hospital. Constant intakes of water and food were carefully maintained throughout the various experiments. Analyses were not made until three days had elapsed after the onset of the regimen.

(a) Restricted salt intake with a moderate caloric intake. This diet contained 2010 calories, with $294 \mathrm{gm}$. carbohydrate, $70 \mathrm{gm}$. protein, $52 \mathrm{gm}$. fat. The electrolyte content was $60.2 \mathrm{mEq}$. potassium, $19.2 \mathrm{mEq}$. sodium, and $13.5 \mathrm{mEq}$. chloride.

(b) Restricted salt intake with increased caloric intake. This diet contained 3475 calories, with $436 \mathrm{gm}$. carbohydrate, $155 \mathrm{gm}$. protein, and $123 \mathrm{gm}$. fat. The electrolyte content was $96.4 \mathrm{mEq}$. potassium, $37.4 \mathrm{mEq}$. sodium, and $25.9 \mathrm{mEq}$. chloride.

Food values were taken from tables $(16,17)$ except for the unsalted bread which was analyzed for sodium, chloride and potassium. The effects of increased amounts of salt were studied subsequently by addition of 72.4 mEq. ( $4.2 \mathrm{gm}$.) of sodium chloride to the above diets. The fluid intake was maintained at a constant level of 2000 cc. daily. All patients were weighed daily under similar conditions.

\section{MATERIAL}

Seven patients with cirrhosis 1 were selected. Three were asymptomatic at the time of the investigation (D. B., G. O., and R. S.).

D. B., a chronic alcoholic male, age 44 , has never experienced symptoms referable to the liver. Physical examination demonstrated a large, firm liver; biopsy disclosed scarring and diffuse fatty infiltration.

G. O., a 52-year-old female, had been seriously ill with ascites, edema, jaundice and liver failure for nearly three and one-half years. Treatment elsewhere had consisted chiefly of repeated paracenteses and administration of diuretics with no restriction of salt intake. Clinical recovery later ensued despite the persistence of coma for three days after an abdominal paracentesis. Her nutrition progressively improved and she has remained free of symptoms for three years. Tests of hepatic function paralleled the clinical course, the only persisting abnormality being a 30 to 40 per cent retention of bromsulfalein.

\footnotetext{
1 The term cirrhosis is employed in a general sense; the fundamental process seemed to be that of a chronic hepatitis.
} 
The third asymptomatic case, R. S., a 45-year-old male, also recovered on medical management. He has remained well for approximately three years. Laboratory evidence of recovery of parenchymal function was obtained concurrently. Bromsulfalein retention (13 per cent) was the only persistent abnormality.

The remaining four cases are described as follows:

P. F., a 49-year-old chronic alcoholic male with ascites of nine months' duration. He had undergone elsewhere 11 paracenteses, with a rapid downhill course. The chief physical findings at the time of study were emaciation and anasarca, with ascites.

D. C., a 58-year-old white male, with a long history of chronic alcoholism and arteriosclerotic cardiovascular disease. Ascites had appeared six months prior to this study. A posterior myocardial infarction followed abdominal paracentesis a month later. Physical examination indicated emaciation, anasarca and ascites. There was no jaundice.

R. D., a 58-year-old white male, had developed jaundice, edema and ascites five months previously. He had not taken alcoholic beverages nor had he experienced any illness that could be interpreted as previous liver disease. Physical examination demonstrated malnutrition, jaundice, and enlargement of the liver and spleen. Histological examination of a needle biopsy of the liver disclosed dilatation of the sinusoids and a diffuse interstitial fibrosis.

A. M., a 45-year-old white female, developed postnecrotic scarring of the liver, edema and ascites, and a tremendous increase in the collateral circulation of the abdomen following massive toxic necrosis of the liver, after the intake of drugs to reduce body weight (benzedrine and probably dinitrophenol).

The urea clearance was normal in six patients and abnormal in only one, A. M. $-(\mathrm{UV} / \mathrm{B}=10)$. The ability to dilute and concentrate urine also was greatly reduced in this case; renal damage apparently had occurred at the time of the massive necrosis of the liver.

Two normal young men, aged 23 (R. B.) and 20 (A. S.) were studied similarly as controls.

\section{Blood}

RESULTS

Plasma volume, hematocrit, proteins and electrolyte concentrations in the serum were determined on the first day of study (Table I). The electrolyte values in the latent case (A) and in patients recovered from ascites (B) were within normal limits (Table I). Two patients with ascites (P. F. and A. M.) had low serum sodium and chloride concentrations; the serum $\mathrm{CO}_{2}$ and $\mathrm{pH}$ were not significantly altered.

The plasma volume varied. In one case, P. F., the volume was $5,063 \mathrm{cc}$. with an hematocrit of 31 ; in another, A. M., hemoconcentration was present with an hematocrit of 55.0 and a plasma volume of $2,804 \mathrm{cc}$. (Table II). As shown later in this study, the plasma volume may be either normal, increased in hemodilution, or reduced in hemoconcentration. As was to be expected, the concentrations of total plasma proteins and plasma albumin were markedly depressed in all cases with ascites. The values were within normal limits in the group with asymptomatic cirrhosis. The non-protein nitrogen was elevated in the patient (A. M.) with marked impairment of renal funcțion.

\section{Water and electrolyte output in the urine}

The daily excretion of urine and electrolytes in the urine was measured in six-day periods; the results are expressed as average daily outputs. Studies were made after constant daily intake of a diet containing $70 \mathrm{gm}$. of protein, $293 \mathrm{gm}$. of carbohydrate, and $62 \mathrm{gm}$. of fat, with a total of

TABLE I

Plasma volume and concentration of serum electrolytes and proteins in cirrhosis with and without ascites

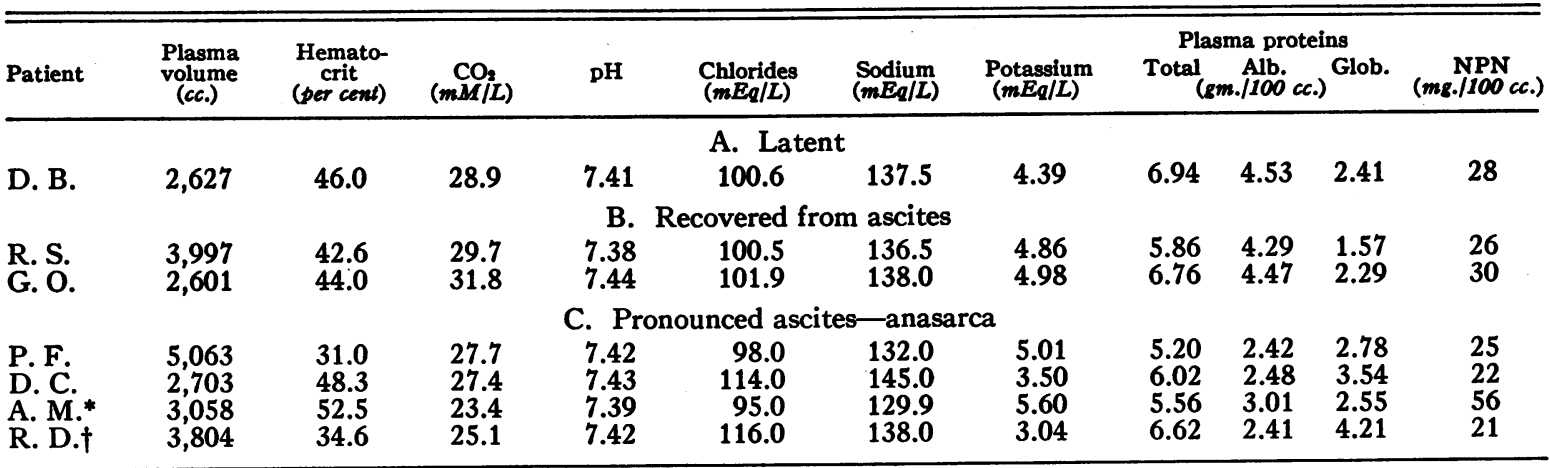

* Post-necrotic cirrhosis.

$\dagger$ Atypical cirrhosis. 
TABLE II

Serum electrolytes, protein and blood volume changes following administration of salt-poor human albumin

\begin{tabular}{|c|c|c|c|c|c|c|c|c|c|c|c|c|c|}
\hline Patient & Days & $\begin{array}{l}\text { Hemato- } \\
\text { crit } \\
\text { (per cent) }\end{array}$ & $\begin{array}{c}\text { Plasma } \\
\text { volume } \\
(c c .)\end{array}$ & $\begin{array}{c}\mathrm{CO}_{2} \\
(m M / L)\end{array}$ & $\mathrm{pH}$. & \multicolumn{2}{|c|}{ Serum } & $\begin{array}{c}\mathrm{K} \\
(m E q / L)\end{array}$ & $\begin{array}{c}\text { NPN } \\
\begin{array}{c}\text { (mg. per } \\
\text { cent })\end{array}\end{array}$ & \multicolumn{2}{|c|}{$\begin{array}{l}\text { Plasma } \\
\text { Total Alb. } \\
\end{array}$} & Glob. & $\begin{array}{c}\text { Daily } \\
\mathrm{Na} \\
\text { intake } \\
(m E q)\end{array}$ \\
\hline \multirow[t]{3}{*}{$\underset{\text { (Figure 3) }}{\text { P. F. }}$} & $\begin{array}{r}7 \\
12\end{array}$ & $\begin{array}{l}30.5 \\
29.5\end{array}$ & $\begin{array}{l}3,793 \\
4,527\end{array}$ & $\begin{array}{l}30 \\
28\end{array}$ & - & $\begin{array}{c}97 \\
100.5\end{array}$ & $\begin{array}{l}133 \\
136\end{array}$ & $\begin{array}{l}4.17 \\
5.07\end{array}$ & $\begin{array}{l}30 \\
28\end{array}$ & $\begin{array}{l}7.16 \\
7.07\end{array}$ & $\begin{array}{l}3.41 \\
3.32\end{array}$ & $\begin{array}{l}3.75 \\
3.75\end{array}$ & $\begin{array}{l}109.7 \\
109.7\end{array}$ \\
\hline & $\begin{array}{l}300 \mathrm{gm} \\
19 \\
22 \\
300 \mathrm{gm}\end{array}$ & $\begin{array}{l}\text { 1. salt-poo } \\
28.0 \\
26.0 \\
\text { salt-poo }\end{array}$ & $\begin{array}{c}\text { albumin } \\
4,885 \\
5,504 \\
\text { albumin }\end{array}$ & 27 & 7.42 & 101.4 & $\underline{137}$ & $\begin{array}{l}4.59 \\
-\end{array}$ & $\begin{array}{l}30 \\
30\end{array}$ & $\begin{array}{l}7.34 \\
7.49\end{array}$ & $\begin{array}{l}4.48 \\
3.97\end{array}$ & $\begin{array}{l}2.86 \\
3.55\end{array}$ & $\begin{array}{l}109.7 \\
109.7\end{array}$ \\
\hline & $\begin{array}{l}25 \\
30\end{array}$ & $\begin{array}{l}19.0 \\
26.0\end{array}$ & $\begin{array}{l}5,916 \\
5,400\end{array}$ & $\overrightarrow{26}$ & $\overline{7.43}$ & $\overline{101.2}$ & $\overline{137}$ & $\overline{4.37}$ & $\begin{array}{l}31 \\
30\end{array}$ & $\begin{array}{l}7.36 \\
7.10\end{array}$ & $\begin{array}{l}4.91 \\
4.28\end{array}$ & $\begin{array}{l}2.45 \\
2.41\end{array}$ & $\begin{array}{l}37.3 \\
37.3\end{array}$ \\
\hline \multirow[t]{3}{*}{ D. C. } & $\begin{array}{c}52 \\
57 \\
525 \mathrm{gm}\end{array}$ & $\begin{array}{c}36.0 \\
36.5 \\
\text { salt-poo }\end{array}$ & $\begin{array}{c}3,050 \\
3,614 \\
\text { albumin }\end{array}$ & $\begin{array}{l}26 \\
26\end{array}$ & $\begin{array}{l}7.41 \\
7.36\end{array}$ & $\begin{array}{l}111 \\
108\end{array}$ & $\begin{array}{l}136 \\
138\end{array}$ & $\begin{array}{l}3.2 \\
3.6\end{array}$ & $\begin{array}{l}21 \\
22\end{array}$ & $\begin{array}{l}5.58 \\
5.41\end{array}$ & $\begin{array}{l}2.52 \\
2.34\end{array}$ & $\begin{array}{l}3.06 \\
3.07\end{array}$ & $\begin{array}{l}19.2 \\
19.2\end{array}$ \\
\hline & $\begin{array}{l}64 \\
225 \mathrm{gm}\end{array}$ & $\begin{array}{c}33.0 \\
\text { salt-poo }\end{array}$ & $\begin{array}{c}3,272 \\
\text { albumin }\end{array}$ & 27 & 7.43 & 107 & 138 & 3.6 & 29 & 6.44 & 4.48 & 1.96 & 19.2 \\
\hline & $\begin{array}{l}68 \\
73\end{array}$ & 32.8 & - & $\begin{array}{l}27 \\
26\end{array}$ & $\begin{array}{l}7.51 \\
7.43\end{array}$ & $\begin{array}{l}108 \\
110\end{array}$ & $\begin{array}{l}137 \\
136\end{array}$ & $\begin{array}{l}3.5 \\
3.5\end{array}$ & 23 & $\begin{array}{l}6.86 \\
6.68\end{array}$ & $\begin{array}{l}4.77 \\
4.12\end{array}$ & $\begin{array}{l}2.09 \\
2.56\end{array}$ & $\begin{array}{l}19.2 \\
19.2\end{array}$ \\
\hline \multirow[t]{3}{*}{ R. D. } & $\begin{array}{c}1 \\
6 \\
450 \mathrm{gm}\end{array}$ & $\begin{array}{c}34.6 \\
36.0 \\
\text { salt-poo }\end{array}$ & $\begin{array}{c}3,804 \\
4,542 \\
\text { albumin }\end{array}$ & $\begin{array}{l}25 \\
27\end{array}$ & $\begin{array}{l}7.52 \\
7.51\end{array}$ & $\begin{array}{l}121 \\
116\end{array}$ & $\begin{array}{l}138 \\
138\end{array}$ & $\begin{array}{l}3.4 \\
3.6\end{array}$ & $\begin{array}{l}21 \\
27\end{array}$ & $\begin{array}{l}6.62 \\
6.64\end{array}$ & $\begin{array}{l}2.41 \\
2.44\end{array}$ & $\begin{array}{l}4.21 \\
4.20\end{array}$ & $\begin{array}{l}19.2 \\
19.2\end{array}$ \\
\hline & $\begin{array}{c}12 \\
450 \mathrm{gm}\end{array}$ & $\begin{array}{c}32.0 \\
\text { salt-poo }\end{array}$ & $\begin{array}{l}3,879 \\
\text { albumin }\end{array}$ & 24 & 7.46 & 108 & 150 & 3.2 & 29 & 7.99 & 5.29 & 2.78 & 19.2 \\
\hline & $\begin{array}{l}18 \\
33\end{array}$ & $\begin{array}{l}29.0 \\
31.0\end{array}$ & $\begin{array}{l}4,147 \\
3,296\end{array}$ & $\begin{array}{l}27 \\
27\end{array}$ & $\begin{array}{l}7.46 \\
7.37\end{array}$ & $\begin{array}{l}111 \\
115\end{array}$ & $\begin{array}{l}151 \\
142\end{array}$ & $\begin{array}{l}3.6 \\
3.3\end{array}$ & $\begin{array}{l}42 \\
24\end{array}$ & $\begin{array}{l}8.28 \\
7.44\end{array}$ & $\begin{array}{l}5.86 \\
4.01\end{array}$ & $\begin{array}{l}2.42 \\
3.43\end{array}$ & $\begin{array}{l}19.2 \\
19.2\end{array}$ \\
\hline \multirow[t]{2}{*}{ A. M. } & $\begin{array}{c}6 \\
450 \mathrm{gm}\end{array}$ & $\begin{array}{c}55.0 \\
\text { salt-poo }\end{array}$ & $\begin{array}{c}2,804 \\
\text { albumin }\end{array}$ & 22 & 7.37 & 82 & 113 & - & 61 & 5.36 & 2.67 & 2.69 & 19.2 \\
\hline & $\begin{array}{l}12 \\
16\end{array}$ & $\begin{array}{l}44.0 \\
44.0\end{array}$ & $\begin{array}{l}3,526 \\
3,600\end{array}$ & $\begin{array}{l}23 \\
22\end{array}$ & $\overline{7.37}$ & $\begin{array}{l}90 \\
92.8\end{array}$ & $\begin{array}{l}123 \\
125\end{array}$ & - & $\begin{array}{l}59 \\
52\end{array}$ & $\begin{array}{l}5.99 \\
5.90\end{array}$ & $\begin{array}{l}4.74 \\
3.85\end{array}$ & $\begin{array}{l}1.23 \\
2.05\end{array}$ & $\begin{array}{l}19.2 \\
19.2\end{array}$ \\
\hline
\end{tabular}

2,010 calories. The daily intake of water was $2,000 \mathrm{cc}$., of sodium $19.2 \mathrm{mEq}$., chloride $13.5 \mathrm{mEq}$., and potassium $60.2 \mathrm{mEq}$. On this sodium chloride restricted diet, all patients with ascites manifested minimal excretion of sodium and chloride (Table III). Oliguria occurred under these conditions only in the one case with ascites and impaired renal function (A. M.).

TABLE III

Average daily excretion of urine and electrolytes during constant intake of 2,000 cc. of water, $60.2 \mathrm{mEq}$ of potassium, $19.2 \mathrm{mEq}$ of sodium, and $13.5 \mathrm{mEq}$ of chlorides*

\begin{tabular}{lcccc}
\hline \hline Patient & $\begin{array}{c}\text { Volume } \\
(c c .)\end{array}$ & $\begin{array}{c}\text { Chlorides } \\
(m E q)\end{array}$ & $\begin{array}{c}\text { Sodium } \\
(m E q)\end{array}$ & $\begin{array}{c}\text { Potassium } \\
(m E q)\end{array}$ \\
\hline \multicolumn{5}{c}{ Normals } \\
R. B. & 1,810 & 41.9 & 32.2 & 58.1 \\
A. S. & 1,437 & 30.6 & 20.9 & 34.0 \\
\multicolumn{5}{c}{ Marked ascites-anasarca } \\
P. F. & 1,632 & 2.97 & 0.57 & 20.6 \\
D. C. & 1,633 & 8.2 & 1.94 & 38.8 \\
A. M. & 645 & 5.4 & 1.80 & 26.6 \\
\hline
\end{tabular}

* Six-day periods of study.

The salt intake had been unrestricted prior to this study. Analyses were made three days after the onset of the regimen.
The addition of $72.4 \mathrm{mEq}$. of sodium chloride to the diet resulted in oliguria in all cases with ascites (Table IV). The excretion of sodium and chloride remained low in patients with ascites.

TABLE IV

Average daily excretion of urine and electrolytes during constant intake of 2,000 cc. of water, $96.4 \mathrm{mEq}$ of potassium, $109.7 \mathrm{mEg}$ of sodium, and $108.3 \mathrm{mEq}$ of chlorides*

\begin{tabular}{|c|c|c|c|c|}
\hline Patient & $\begin{array}{c}\text { Volume } \\
(c c .)\end{array}$ & $\underset{(m E q)}{\text { Chlorides }}$ & $\underset{(m E q)}{\text { Sodium }}$ & $\underset{(m E q)}{\text { Potassium }}$ \\
\hline \multicolumn{5}{|c|}{ Normals } \\
\hline $\begin{array}{l}\text { R. B. } \\
\text { A. S. }\end{array}$ & $\begin{array}{l}1,070 \\
1,280\end{array}$ & $\begin{array}{l}106.5 \\
118.2\end{array}$ & $\begin{array}{l}101.2 \\
118.0\end{array}$ & $\begin{array}{l}59.9 \\
77.0\end{array}$ \\
\hline \multicolumn{5}{|c|}{$\begin{array}{l}\text { Cirrhosis } \\
\text { A. Latent }\end{array}$} \\
\hline D. B. & 892 & 62.5 & 50.1 & 65.9 \\
\hline \multicolumn{5}{|c|}{ B. Recovered from ascites } \\
\hline $\begin{array}{l}\text { R. S. } \\
\text { G. O. }\end{array}$ & $\begin{array}{l}1,666 \\
1,825\end{array}$ & $\begin{array}{r}86.7 \\
114.1\end{array}$ & $\begin{array}{l}104.8 \\
102.6\end{array}$ & $\begin{array}{l}74.5 \\
80.4\end{array}$ \\
\hline \multicolumn{5}{|c|}{ C. Marked ascites-anasarca } \\
\hline $\begin{array}{l}\text { P. F. } \\
\text { D. C. } \\
\text { A. M. }\end{array}$ & $\begin{array}{l}973 \\
756 \\
546\end{array}$ & $\begin{array}{r}16.7 \\
6.3 \\
4.8\end{array}$ & $\begin{array}{l}0.33 \\
2.0 \\
1.04\end{array}$ & $\begin{array}{l}31.6 \\
19.2 \\
20.8\end{array}$ \\
\hline
\end{tabular}

* Six-day periods of study.

The salt intake was unrestricted prior to this study. 
Relation of electrolyte excretion in the urine to the serum electrolytes

No relation was found between the concentrations of electrolytes in the serum or the ascitic fluid and those in the urine; this observation is illustrated in a patient (D. B.) in whom the concentration of serum electrolytes was normal but the excretion of sodium chloride in the urine was minimal. Similar observations have been made by Farnsworth and Krakusin (1).

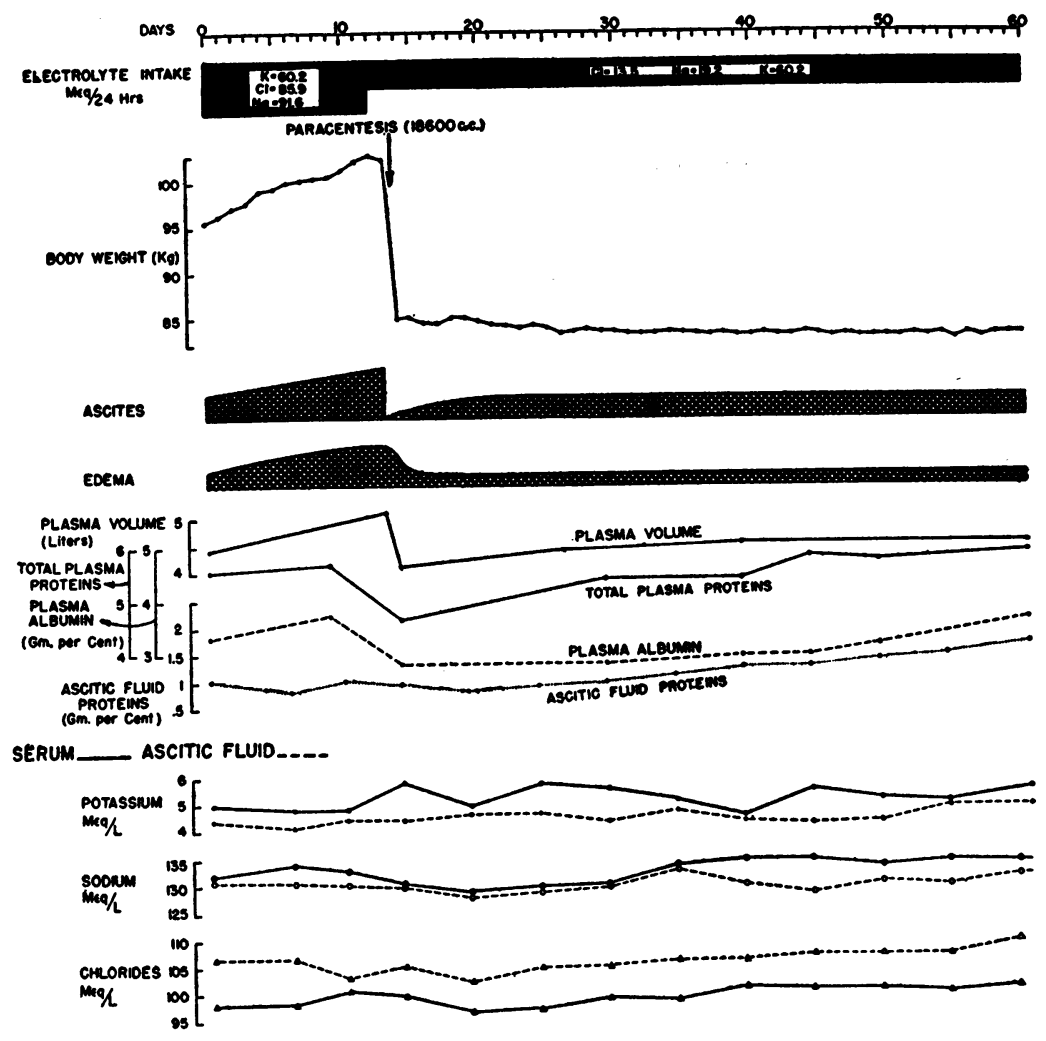

URINE

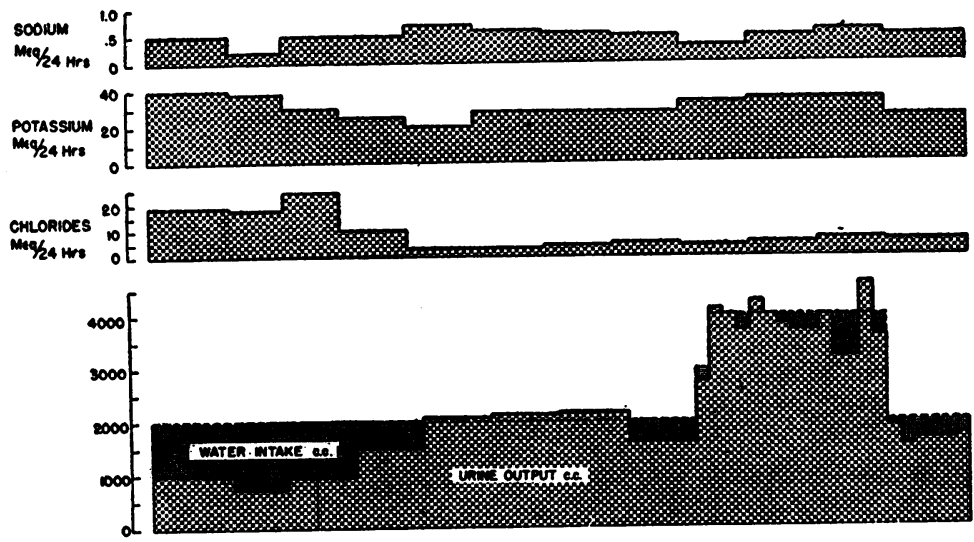

Fig. 1. (Case P. F.) Effects of Paracentesis, Restriction of Salt Intake, and Large Water Intake on Edema, Ascites, Body Weight; on the Concentration of Plasma Proteins and Electrolytes in the Serum and Ascitic Fluid; ANd on Excretion of Water and Electrolytes in the Urine 
Relation of the concentration of plasma albumin and excretion of salt by the kidney

The pronounced decrease in urinary excretion of sodium and chloride in the cases with ascites, in whom the plasma albumin was markedly di- minished, suggested some relationship between the colloid-osmotic pressure of the blood and the ability of the kidneys to regulate salt excretion. It will be shown later, however, that the administration of salt-poor human albumin did not con-

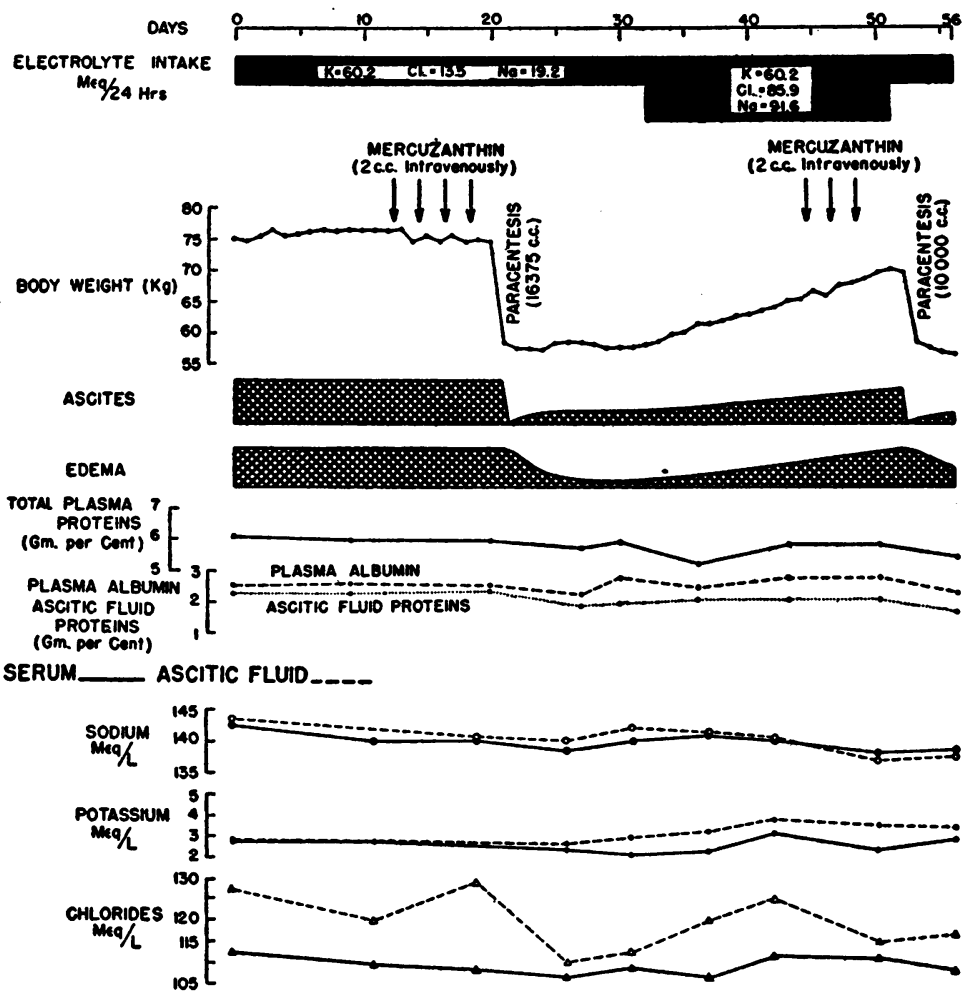

URINE

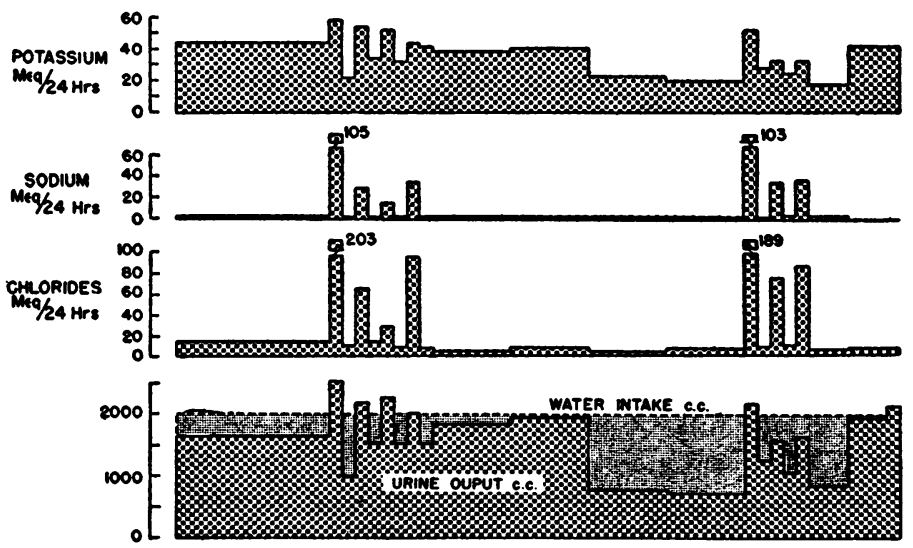

Fig. 2. (CAse D. C.) Experiment Disclosing Inability to Control Progressive Body Fluid Retention in a Patient with Ascites, in Whom Salt Intake Was Not Restricted, by Administration of Mercurial Diuretics

Marked oliguria follows increase of salt intake without increase in the excretion of sodium in the urine. 
sistently increase the diminished urinary excretion of sodium chloride.

\section{Portal Cirrhosis with Ascites}

The effects of $(a)$ a restricted sodium chloride intake, $(b)$ an increased water intake, $(c)$ diuretics, $(d)$ paracentesis, and $(e)$ administration of parenteral protein were studied in four cases of portal cirrhosis with ascites.

\section{(a) 19.2 mEq. sodium daily intake}

The effects of a low-salt intake were observed in four cases for periods varying from six to 48 days. All patients became accustomed to the lowsalt intake and were able to eat adequately. The transition from an unrestricted to limited salt intake of the type specified above (Figures 1 and 2), resulted in an increase in the average daily excretion of urine; the body weight decreased or was unchanged. The edema and ascites did not progress. Hyponatremia was not observed in these patients.

An additional $4.2 \mathrm{gm}$. (74.2 $\mathrm{mEq}$.) sodium chloride intake. The addition of $4.2 \mathrm{gm}$. (74.2 $\mathrm{mEq}$.) of sodium chloride to the diet of two patients (D. C. and P. F.) in whom the accumulation of fluid was controlled with $19.2 \mathrm{mEq}$. of sodium, (Figures 2 and 3), resulted in a decrease in the average daily urine excretion, progressive and rapid increase in body weight, edema and ascites. There was no significant alteration in the concentration of serum or ascitic fluid electrolytes. Pronounced dehydration or hemoconcentration was not observed during the use of this diet, probably because the intake of water was not restricted and the intake of sodium in this particular study was not large; however, one patient (D. C.) complained of thirst.

\section{(b) Increased water intake}

Administration of large amounts of water parenterally or by mouth in the presence of an unrestricted salt intake in patients with ascites usually was followed by a great increase in edema, ascites, and body weight. However, in one patient (P. F.-Figure 1) large amounts of water during a daily sodium intake of $19.2 \mathrm{mEq}$. were excreted proportionately so that there was no increase in weight, change of edema, or ascites. The key fac- tor obviously was the intake of salt. There was no increase in the total excretion of sodium in the urine. This evidence is compatible with the concept of increased reabsorption of sodium chloride by the renal tubules.

\section{(c) Diuretics}

Evaluation of diuretics was limited to three: ammonium chloride, mercurials, and aminophyllin.

Ammonium chloride. Ammonium chloride was studied in three patients maintained on a 19.2 $\mathrm{mEq}$. sodium daily intake, for a period of from four to ten days. The effects in the three cases were similar, and are especially well illustrated in one patient (P. F.-Figure 4). The administration of $6 \mathrm{gm}$. of ammonium chloride daily by mouth increased the elimination of chloride but did not alter the daily excretion of urine or the excretion of sodium or potassium; there was no change in body weight or in the degree of edema or ascites.

Mercurial diuretics. A mercurial diuretic (Mercuzanthin, $2 \mathrm{cc}$. $)^{2}$ was administered to three patients with ascites (D. C., R. D., and P. F.), maintained on a restricted salt intake. In all cases, the diuretic increased the urine volume, the excretion of sodium and chloride, and to a lesser extent, the excretion of potassium (Figures 2 and 4).

Response to the mercurial diuretic varied considerably. Its maximum effect occurred during the first few injections and then decreased (Figure 4). In one patient, maintained on a $19.2 \mathrm{mEq}$. sodium intake daily for 48 days, an initial mercurial injection produced a diuresis of $5,550 \mathrm{cc}$. of urine with a total excretion of $550 \mathrm{mEq}$. of sodium/24 hours. Twelve days later, however, the administration of the same diuretic produced an excretion of only $2,000 \mathrm{cc}$. of urine and $52.8 \mathrm{mEq}$. of sodium.

The decrease in body weight, reduction of edema, ascites, and plasma volume paralleled the intensity of the diuretic effect. The administration of ammonium chloride in one experiment enhanced the diuretic action of Mercuzanthin.

Aminophyllin. Intravenous aminophyllin (20 cc.) also increased the excretion of sodium and 
chloride in the urine, with a slight increase in the total excretion of water. These effects were comparable to those produced by administration of intravenous mercurial diuretics, but less intense (Figure 4).
Effects of diuretics with $72.4 \mathrm{mEq}$. of sodium chloride added to the diet. Similar results in the elimination of sodium and chloride in the urine were observed in cases receiving an additional $72.4 \mathrm{mEq}$. of sodium chloride. Under these cir-

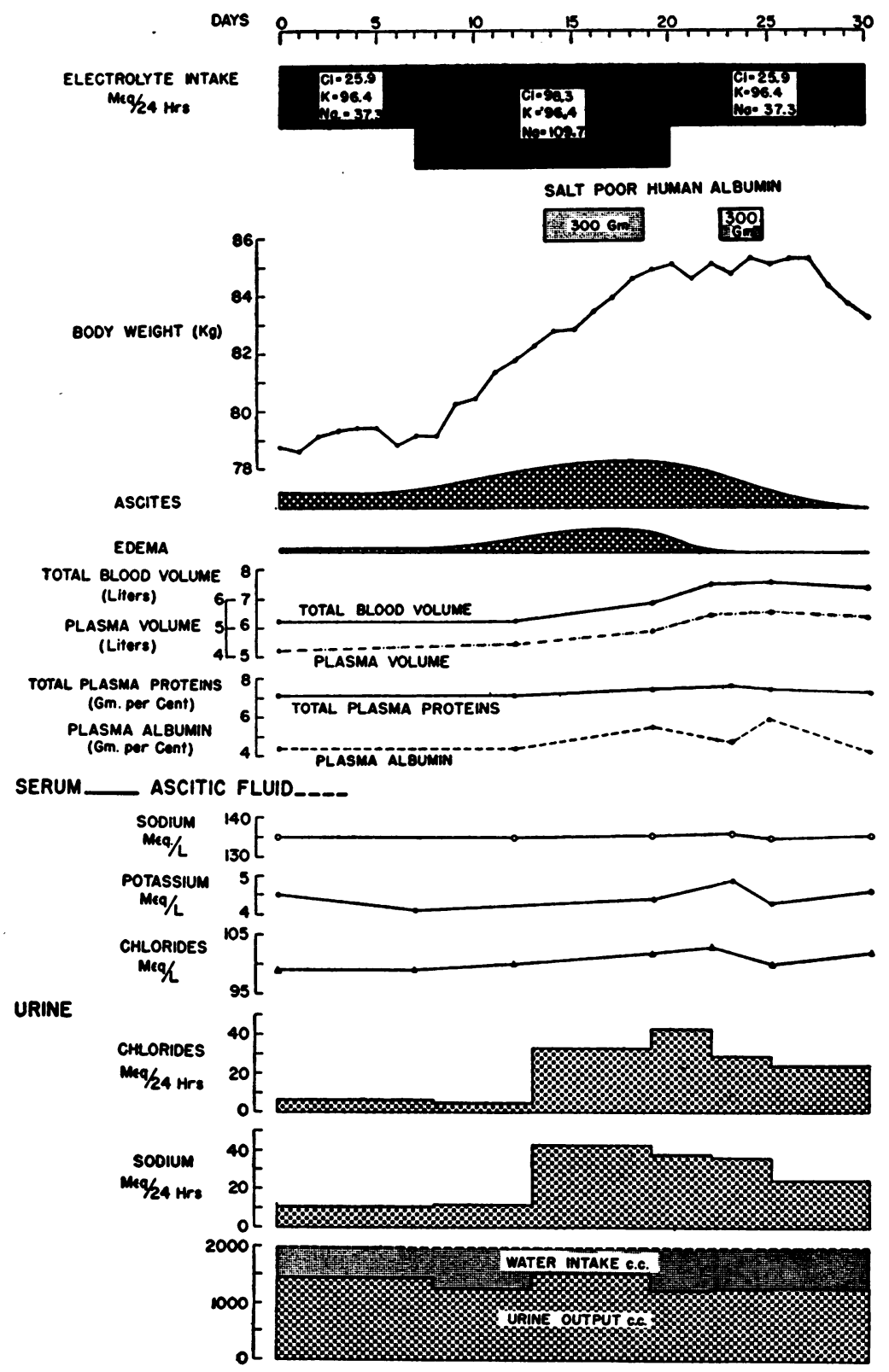

Fig. 3. (Case P. F.) Effects of Infusions of Salt-poor Human Albumin on a Patient with Ascites with or without Control of Sodium INTAKE

Experiment discloses administration of salt-poor human albumin infusions in unrestricted salt intake was followed by increase in edema, ascites and body weight. 
cumstances, however, the administration of diuretics could not control the progressive gain in body weight and increased edema and ascites; under this type of management, retention of water was progressive and ultimately necessitated another paracentesis (Figure 2).

\section{(d) Effects of paracentesis}

Repeated paracenteses, necessitated by the continued accumulation of fluid accompanying the unrestricted intake of salt, lead to serious depletion of protein, electrolytes and body water. The amount of protein and electrolytes withdrawn in
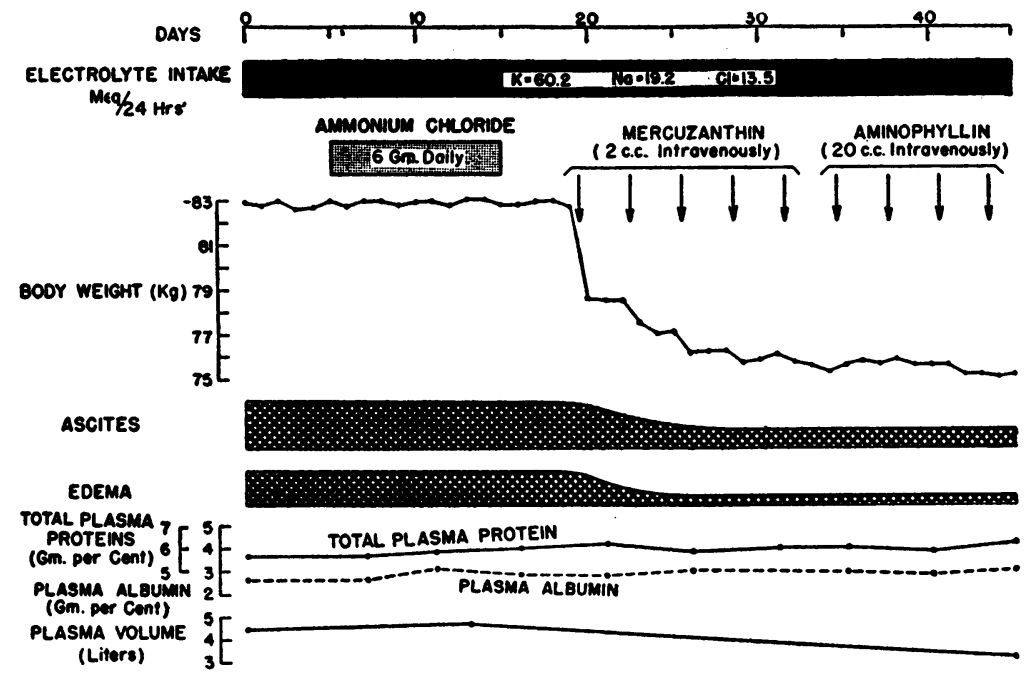

SERUM ASCITIC FLUID

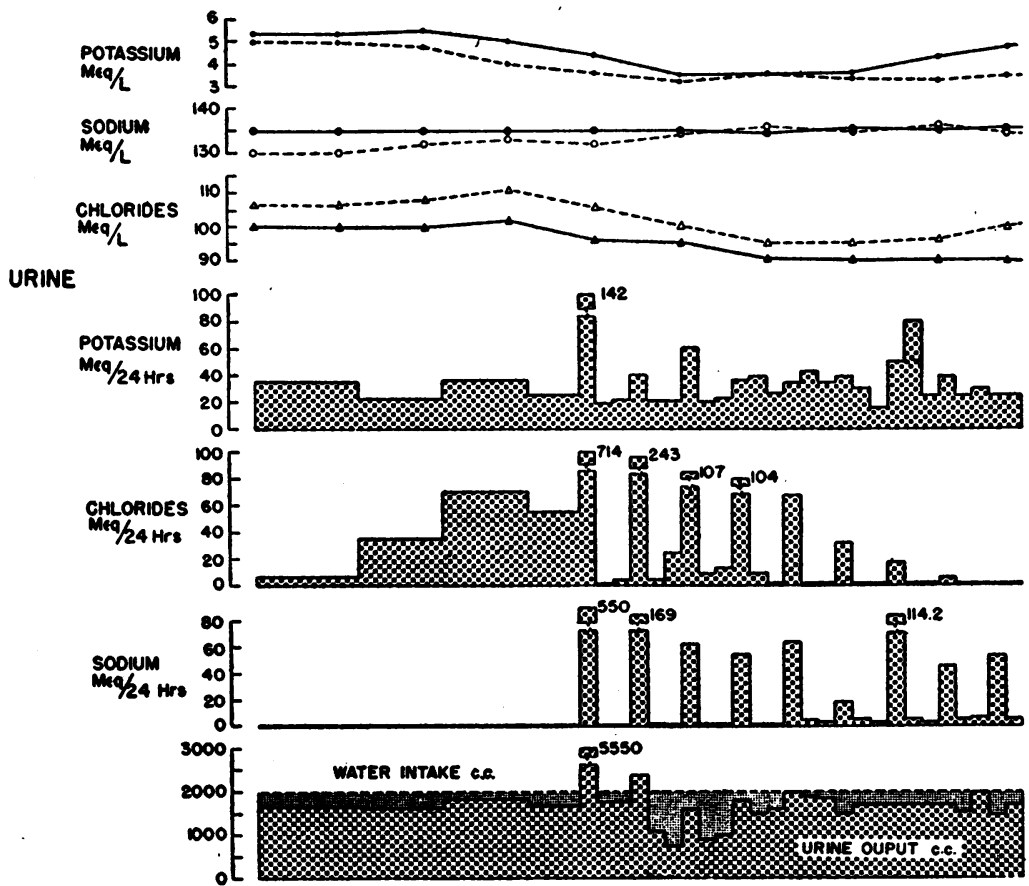

Fig. 4. (Case P. F.) Effects of Diuretics on Body Weight, Edema, Ascites and Plasma Volume, in a Patient with Cirrhosis Maintained on a SALT-RESTRICTEd Diet for 48 Days

Effects on the concentration of plasma proteins, electrolytes in the serum and ascitic fluid, and on the excretion of water and electrolytes in the urine. 
TABLE V

Magnitude of protein and electrolyte loss by paracentesis in portal cirrhosis with ascites

\begin{tabular}{lccccc}
\hline Patient & $\begin{array}{c}\text { Volume } \\
\text { ascitic } \\
\text { fluid } \\
\text { removed } \\
(c c .)\end{array}$ & $\begin{array}{c}\text { Protein } \\
(\mathrm{gm.})\end{array}$ & $\begin{array}{c}\text { Chlorides } \\
(\mathrm{mEq})\end{array}$ & $\begin{array}{c}\text { Sodium } \\
(\mathrm{mEq})\end{array}$ & $\begin{array}{c}\text { Potassium } \\
(\mathrm{mEq})\end{array}$ \\
\hline P. F. & 18,600 & $\begin{array}{c}255 \\
(254)^{*}\end{array}$ & 1,986 & 1,244 & 77 \\
D.C. & 16,375 & $\begin{array}{c}383 \\
(192)\end{array}$ & 2,112 & 2,292 & 52 \\
& 10,000 & $\begin{array}{c}201 \\
(165)\end{array}$ & 1,150 & 1,340 & 40 \\
& 18,000 & $\begin{array}{c}641 \\
(218)\end{array}$ & 2,016 & 2,574 & 54 \\
A. M. & 14,150 & $\begin{array}{c}162 \\
(162)\end{array}$ & 1,627 & 1,782 & 92 \\
& & $(162)$ & & \\
\hline
\end{tabular}

* The figures in parentheses represent the estimated total amount of plasma circulating protein at the time of paracentesis.

a single paracentesis may be considerable as illustrated in Table V. While a single paracentesis may be unavoidable, repeated paracenteses are unnecessary when the sodium intake is restricted to less than $500 \mathrm{mg}$. daily (18). The total loss of protein depends, of course, on the concentration of protein and the amount of ascitic fluid removed (Table V). In one patient (A. M.) $161.5 \mathrm{gm}$. of protein were lost at the time of paracentesis. In another patient (D. C.), who had received saltpoor human albumin three weeks earlier, $641 \mathrm{gm}$. of protein were withdrawn. Furthermore, the loss of sodium chloride and potassium ions was three to five times the estimated total circulating amounts of these ions in the serum.

Paracentesis and adequate restriction of sodium intake usually are not followed by significant change in body weight. Although a considerable shift of interstitial fluid to the abdomen followed paracentesis in the cases with anasarca (Figures 1 and 2), no increase in body weight and no increase in sodium and chloride output in the urine were observed. The reaccumulated ascitic fluid contained approximately the same concentration of electrolytes, and its protein content rose progressively to the original level.

\section{(e) Parenteral administration of protein}

Parenteral administration of protein was accomplished by the administration intravenously of three protein materials: salt-poor albumin, plasma, and blood, given at separate times. The immediate effects of parenteral protein therapy in patients severely depleted of protein and unable to eliminate sodium were related to the protein and the salt administered.

Effects of administration of salt-poor human albumin. The effect of salt-poor albumin administration was studied under two conditions: sodium intake, restricted to $19.2 \mathrm{mEq}$. or $37.3 \mathrm{mEq}$., and during the addition of $72.4 \mathrm{mEq}$. of sodium chloride to those diets.

Restricted sodium intake: The body weight remained stationary or decreased. Edema disappeared in all four cases after administration of

TABLE VI

Effect of administration of salt-poor albumin on the excretion of urine and electrolytes

\begin{tabular}{|c|c|c|c|c|c|c|c|c|c|}
\hline Patient & & Days & $\begin{array}{l}\text { Water } \\
\text { intake }\end{array}$ & $(c c)$. & $\begin{array}{l}\text { Urine } \\
\text { output }\end{array}$ & $\begin{array}{c}\text { Daily } \\
\text { sodium } \\
\text { intake } \\
(m B q)\end{array}$ & $\underset{(m E Q)}{\text { Chlorides }}$ & $\begin{array}{l}\text { Sodium } \\
\text { output } \\
(m E q)\end{array}$ & $\begin{array}{l}\text { Potassium } \\
(m E q)\end{array}$ \\
\hline $\begin{array}{l}\text { P. F. } \\
\text { (Figure 3) }\end{array}$ & $\begin{array}{l}300 \mathrm{gm} \text {. salt-poor albumin } \\
300 \mathrm{gm} \text {. salt-poor albumin }\end{array}$ & $\begin{array}{c}0-7 \\
8-12 \\
13-18 \\
18-22 \\
22-25 \\
25-30\end{array}$ & $\begin{array}{l}2,000 \\
2,000 \\
2,000 \\
2,000 \\
2,000 \\
2,000\end{array}$ & & $\begin{array}{l}1,442 \\
1,280 \\
1,524 \\
1,233 \\
1,288 \\
1,302\end{array}$ & $\begin{array}{r}37.3 \\
109.7 \\
109.7 \\
37.3 \\
37.3 \\
37.3\end{array}$ & $\begin{array}{r}5.9 \\
5.2 \\
33.2 \\
43.3 \\
36.5 \\
24.2\end{array}$ & $\begin{array}{l}11.8 \\
12.7 \\
43.9 \\
38.7 \\
32.2 \\
24.6\end{array}$ & $\begin{array}{l}z \\
z \\
z\end{array}$ \\
\hline D. C. & $\begin{array}{l}525 \mathrm{gm} \text {. salt-poor albumin } \\
225 \mathrm{gm} \text {. salt-poor albumin }\end{array}$ & $\begin{array}{l}52-57 \\
57-62 \\
62-67 \\
67-72 \\
72-75\end{array}$ & $\begin{array}{l}2,000 \\
2,000 \\
2,000 \\
2,000 \\
2,000\end{array}$ & & $\begin{array}{l}1,995 \\
2,187 \\
1,845 \\
1,906 \\
1,850\end{array}$ & $\begin{array}{l}19.2 \\
19.2 \\
19.2 \\
19.2 \\
19.2\end{array}$ & $\begin{array}{r}6.26 \\
11.17 \\
4.53 \\
5.95 \\
6.19\end{array}$ & $\begin{array}{l}0.5 \\
2.51 \\
0.77 \\
0.52 \\
0.82\end{array}$ & $\begin{array}{l}41.2 \\
48.7 \\
38.6 \\
39.1 \\
37.1\end{array}$ \\
\hline A. $\mathbf{M}$. & $450 \mathrm{gm}$. salt-poor albumin & $\begin{array}{c}1-6 \\
6-12 \\
12-16\end{array}$ & $\begin{array}{l}1,666 \\
1,700 \\
1,446\end{array}$ & & $\begin{array}{l}645 \\
707 \\
906\end{array}$ & $\begin{array}{l}19.2 \\
19.2 \\
19.2\end{array}$ & $\begin{array}{l}5.4 \\
5.3 \\
5.7\end{array}$ & $\begin{array}{l}1.8 \\
2.0 \\
4.1\end{array}$ & $\begin{array}{l}26.6 \\
18.7 \\
24.4\end{array}$ \\
\hline
\end{tabular}


225 to $900 \mathrm{gm}$. of salt-poor human albumin. Ascites disappeared rapidly in two cases (R. D. and P. F.), and was not significantly altered in two (A. M. and D. C.). In these latter two patients, body weight remained stationary, but their general condition was greatly improved.

Infusions of albumin were followed by an in- constant increase in the excretion of urine. A slight rise in the average daily excretion occurred in two cases (A. M. and R. D.). In one of these patients, A. M. (Table VI), in whom renal function was impaired, the oliguria persisted. In two cases (P. F. and D. C.) the excretion of urine did not vary significantly.

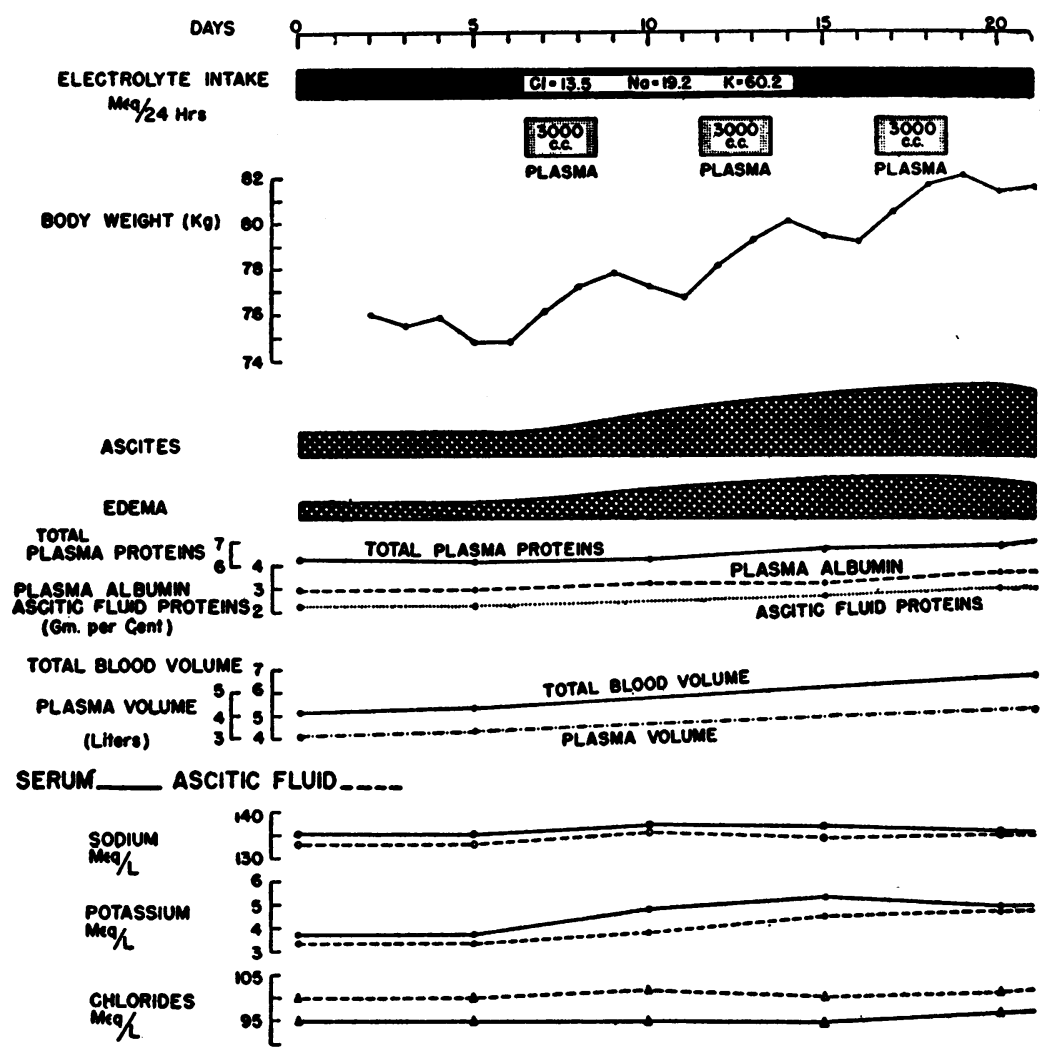

URINE

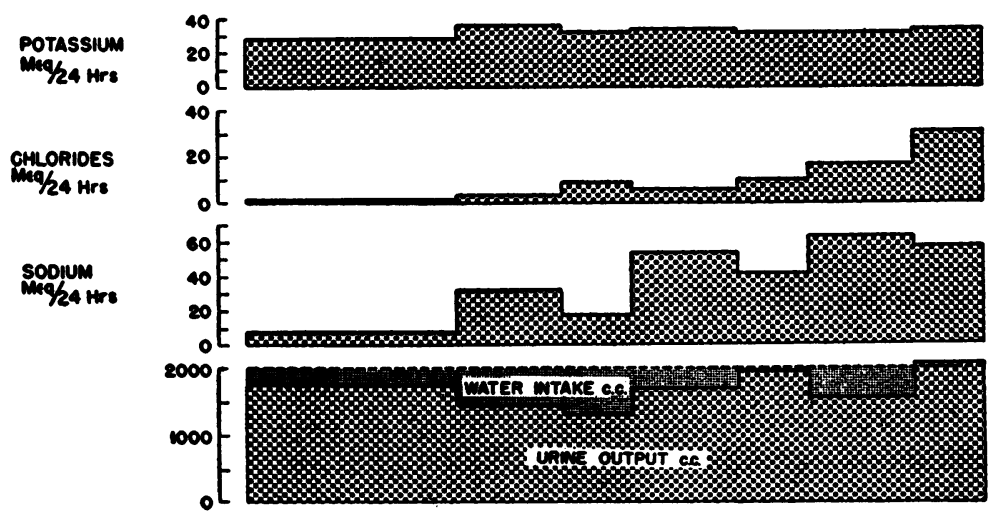

Fig. 5. (Case P. F.) Effects of Plasma Infusions on Body Weight, Edema and Ascites; on the Concentration of Plasma Proteins and Electrolytes in the Serum; ANd ON THE Excretion of Electrolytes in the URINE 
The changes in plasma volume were variable (Table II). A slight decrease was observed in two of the four cases with ascites (R. D. and D. C.) ; this, however, was not due to hemoconcentration since the hematocrit values also decreased. In a third patient (P. F.) the plasma volume did not change significantly; in the fourth case (A. M.), with marked hemoconcentration and dehy- dration, the administration of $450 \mathrm{gm}$. of salt-poor albumin in six days was followed by a decrease in the hematocrit from 55 to 44 and an increase in the plasma volume from 2,804 to $3,526 \mathrm{cc}$. The concentration of protein in the plasma and in the ascitic fluid increased markedly, as noted in previous studies (19-23). This increased protein concentration was transitory, as has been previ-

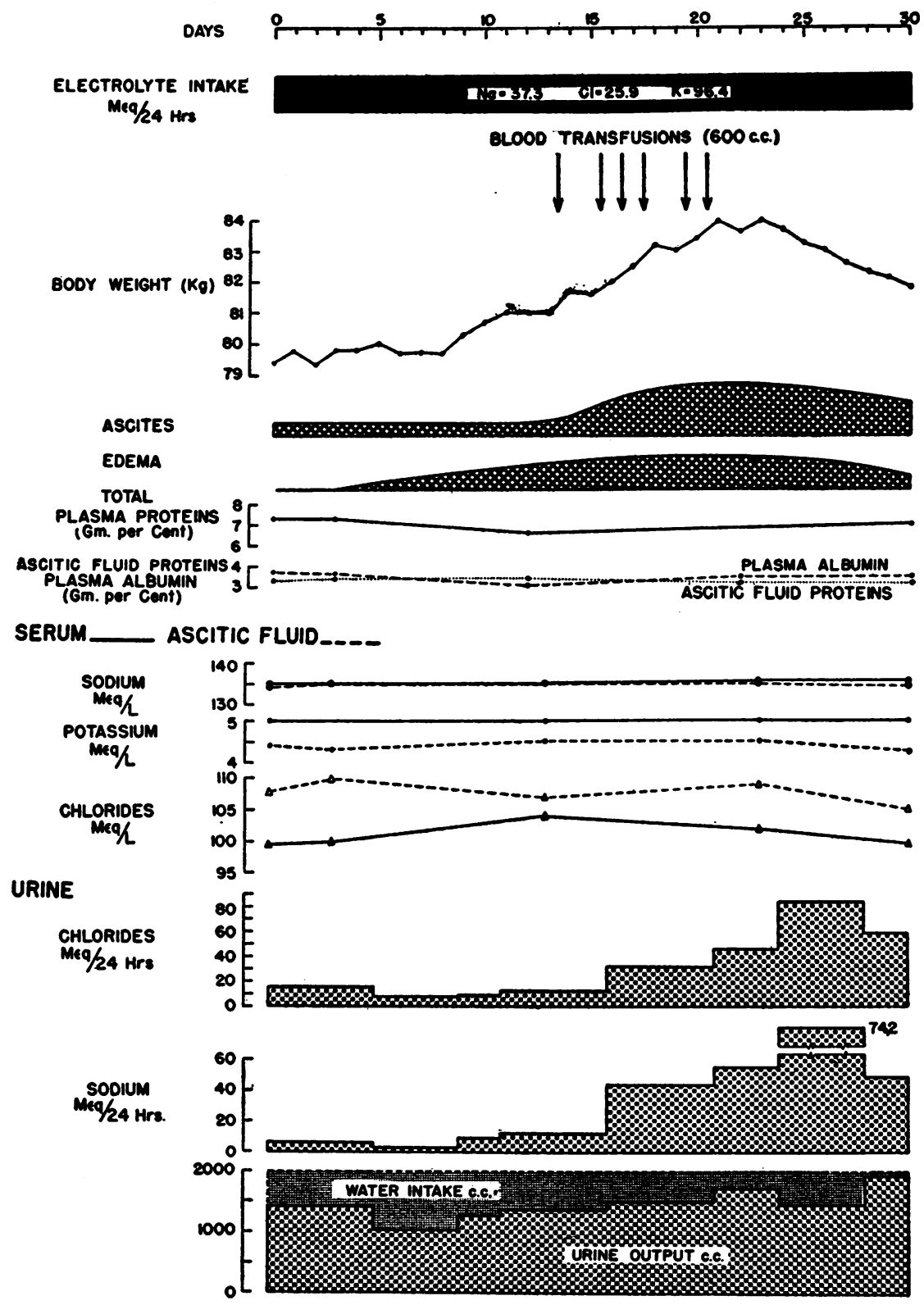

Fig. 6. (Case P. F.) Effects of Blood Transfusions on Body Weight, Edema and Ascites; on Concentration of Plasma Proteins and Electrolytes in the Serum and Ascitic Fluid; and on the Excretion of Electrolytes in the Urine 
ously observed (19-22). Since the changes in the serum electrolytes and ascitic fluid electrolytes paralleled each other, only alteration in the serum electrolytes will be discussed. The administration of salt-poor albumin produced no significant changes in the serum electrolytes in two cases (D. C. and P. F.) with initially normal serum electrolytes. In a third patient (R. D.) the administration of $450 \mathrm{gm}$. of albumin in six days raised the concentration of serum sodium from 138 to $150 \mathrm{mEq} . / \mathrm{L}$. In the fourth case (A. M.), with initially lowered concentration of serum sodium and chloride, the administration of $450 \mathrm{gm}$. of salt-poor albumin raised the concentration of serum chloride from 82 to $92 \mathrm{mEq}$./L. and the concentration of serum sodium from 113 to 123 $\mathrm{mEq} . / \mathrm{L}$. in six days.

The excretion of electrolytes in the urine was studied in three cases (Table VI). In two (P. F. and A. M.) the outputs of sodium increased to nearly four times the original levels excreted; but in both instances were less than normal. In one patient (A. M.), after the infusion of salt-poor albumin, the average excretion of sodium was approximately $4 \mathrm{mEq}$., and in the other (P. F.) it was approximately $40 \mathrm{mEq}$. In a third case (D. C.) there was no significant rise in the elimination of electrolytes after infusion of $750 \mathrm{gm}$. of albumin in ten days.

The administration of salt-poor albumin in one case ( $P . F$. ) increased the sodium excretion in the urine, the augmented output persisting after therapy. In contrast, the increased excretion of electrolytes after the use of mercurial and aminophyllin diuretics was confined to the days of administration.

Salt-poor human albumin administered to patients receiving an additional $72.4 \mathrm{mEq}$. of sodium chloride: The effects of salt-poor human albumin were studied in one patient receiving an additional $72.4 \mathrm{mEq}$. of sodium chloride by mouth (Figure 3). In contradistinction to the $37.3 \mathrm{mEq}$. sodium intake effect, the body weight, edema, and ascites progressively increased. The increased administration of sodium without protein did not increase the excretion of sodium in the urine, as did the administration of albumin. Nevertheless, the effect of albumin was not sufficient to prevent the retention of water.

Plasma and blood transfusions. Transfusions of plasma and blood also supply considerable salt, and therefore tend to increase salt and water retention in patients unable to excrete sodium in the urine. Figure 5 illustrates the effect of nine infusions of plasma, $1000 \mathrm{cc}$. each, in one patient (P.F.). Increases were noted in body weight, edema and ascites, and also in plasma volume. The increased excretion of sodium in the urine was maintained during the days in which the patient did not receive the plasma infusions. Similar effects were noted in the same case after the administration of seven blood transfusions of $500 \mathrm{cc}$. each, namely, increase in body weight, edema and ascites, in plasma volume and in the elimination of sodium in the urine (Figure 6).

\section{DISCUSSION}

Comparative study of patients with cirrhosis of the liver, with and without ascites, provides an excellent opportunity to investigate certain factors implicated in the development of ascites and edema. The important features characteristic of ascites are: depletion of proteins and plasma albumin, and decreased excretion of sodium ion in the urine (18).

The fundamental factors in the formation of edema and ascitic fluid in portal cirrhosis appear to be systemic in origin, rather than anatomical or mechanical. Farnsworth and Krakusin (1) recently demonstrated the marked reduction in output of salt in patients with cirrhosis; similar observations have been reported by others $(2-4)$. The formation of ascitic fluid, an ultrafiltrate of the sera, is influenced by various factors which also influence the formation of interstitial fluid. Among these, systemic causes appear to have a fundamental role. The present study indicates that there is a shift of edema fluid to the abdomen and no change in body weight or in the elimination of electrolytes in the urine following paracentesis in patients maintained on a $19.2 \mathrm{mEq}$. sodium intake as seen clearly in Figure 1. The fundamental ion is sodium and not the chlorides, since administration of ammonium chloride did not significantly alter the retention of fluid as seen in Figure 4. The normal urea clearances in three of the four cases with ascites, and the unimpaired capacity of the kidney to dilute and concentrate urine, indicate normal renal function in these patients, altered only in so far as the increased 
reabsorption of salt is concerned. A recent study (4) has disclosed sodium retention in cirrhosis of the liver with normal mannitol and para-aminohippurate clearances, giving evidence that the retention of salt is due to increased renal tubular reabsorption of salt. That renal disease and liver disease may coexist is illustrated in one case with ascites (A. M.), who had both, following a massive necrosis of the liver with post-necrotic scarring.

The restriction of salt in the present study did not lead to demonstrable salt depletion in these patients. Lower values of sodium chloride in the serum of cases with edema and ascites may be quite misleading, as these patients are not saltdepleted but have an excessive amount of salt distributed in the expanded interstitial fluid. However, administration of salt will increase fluid retention, body weight, edema and ascites (Figures 1 and 2). Oliguria was not observed in cases maintained on restricted salt intakes, becoming evident that if an anti-diuretic principle is involved, as found by Ralli and associates (23) in cases with ascites, this agent must act through increasing salt retention.

The relation between depletion of body proteins and increased reabsorption of salt in the kidney is of paramount importance and is a subject requiring further study. In cases with ascites treated by a long-term program of protein repletion, the edema and ascites disappeared and there was no further tendency to salt and water retention (18). That the colloid-osmotic pressure of the blood, however, is not the regulating factor for salt excretion by the kidney was suggested by the observation that albumin administered intravenously, though raising to normal the total circulating protein and albumin levels, did not correct the diminished salt output. However, in one case (P. F.), there was an increased elimination of salt which lasted after the albumin infusions, an effect not observed following mercurial or aminophyllin injections. The role of hormones, particularly those of the adrenal cortex, also requires further investigation.

\section{SUMMARY}

Seven patients with cirrhosis of the liver were studied to further evaluate the alterations of water and electrolyte metabolism in the disease. Two normal individuals served as controls. The concentrations of sodium, potassium, and chloride were measured in the serum and in cases with ascites in the ascitic fluid as well. The following additional determinations were made: carbon dioxide, $\mathrm{pH}$, non-protein nitrogen in the serum; total protein, albumin and globulin in the plasma; on the ascitic fluid the total protein, plasma volume and hematocrit. All the determinations were made simultaneously at regular intervals. The total daily output of urine, urinary sodium, chloride and potassium were determined.

Four patients had ascites and edema at the time of study. Two had remained symptom-free for more than three years after complete disappearance of edema, ascites, and symptoms of hepatic failure; one, an instance of latent cirrhosis, never reported symptoms referable to liver disease. The diagnosis of cirrhosis was confirmed in all cases by histologic examination of needle biopsies. All studies were made under conditions of constant daily intake of food, calories, water and electrolytes. Periods of observation varied from two weeks to seven months. Studies were made on the effects of a reduced sodium intake of $19.2 \mathrm{mEq}$. daily, $37.3 \mathrm{mEq}$. daily, and during an additional $72.4 \mathrm{mEq}$. of sodium chloride, large water intake, paracentesis, diuretics and parenteral protein administration.

\section{CONCLUSIONS}

1. The urinary excretion of sodium chloride is decreased in patients with portal cirrhosis and ascites. The output of sodium chloride in the urine is not significantly decreased in patients with portal cirrhosis in the absence of ascites.

2. The retention of fluid in cirrhosis is related to retention of the sodium ion; this is not dependent on hypoalbuminemia alone because administration of salt-poor albumin does not correct the deficient salt excretion.

3. Restriction of salt intake is indispensable to the control and management of fluid retention in patients with ascites. Repeated paracenteses and, to a great extent, administration of diuretics can be avoided by adequate restriction of the salt intake.

\section{ACKNOWLEDGMENTS}

The authors are indebted to Dr. Walter L. Palmer for providing some of the facilities necessary for this study; 
to Michael Roma for invaluable technical assistance; to Miss Minnie Brandt and her staff for the preparation and administration of the diets; and to the nursing staff for the care of the patients.

The authors are also indebted to Eli Lilly and Company for providing Evans Blue for plasma volume determinations.

\section{REFERENCES}

1. Farnsworth, E. B., and Krakusin, J. S., Electrolyte partition in patients with edema of various origins. Qualitative and quantitative definitions of cations and anions in hepatic cirrhosis. J. Lab. \& Clin. Med., 1948, 33, 1545.

2. Faloon, W. W., Eckhardt, R. D., Cooper, A. M., and Davidson, C. S., The effect of human serum albumin, mercurial diuretics, and low salt diet on sodium excretion in patients with cirrhosis of the liver. J. Clin. Invest., 1949, 28, 595.

3. Eisenmenger, W. J., Ahrens, E. H., Jr., Blondheim, S. H., and Kunkel, H. G., The effect of rigid sodium restriction in patients with cirrhosis of the liver and ascites. J. Lab. \& Clin. Med., 1949, 34, 1029.

4. Goodyer, A. V. N., Relman, A. S., Lawrason, F. D., and Epstein, F. D., Salt retention in cirrhosis of the liver. J. Clin. Invest., 1950, 29, 973.

5. Butler, A. M., and Tuthill, E., An application of the uranyl zinc acetate method for determination of sodium in biological material. J. Biol. Chem., 1931, 93, 171.

6. Eichelberger, L., and Roma, M., Experimental hydronephrosis in dogs. The composition of blood serum. J. Urol., 1938, 40, 366.

7. Shohl, A. T., and Bennett, H. B., A micro method for the determination of potassium as iodoplatinate. J. Biol. Chem., 1928, 78, 643.

8. Wilson, D. W., and Ball, E. G., A study of the estimation of chloride in blood and serum. J. Biol. Chem., 1928, 79, 221.

9. Van Slyke, D. D., The determination of chlorides in blood and tissues. J. Biol. Chem., 1924, 58, 523.

10. Campbell, W. R., and Hanna, M. I., The albumin, globulins, and fibrinogen of serum and plasma. J. Biol. Chem., 1937, 119, 15.

11. Van Slyke, D. D., and Neill, J. M., The determination of gases in the blood and other solutions by vacuum extraction and manometric measurement. J. Biol. Chem., 1924, 61, 523.
12. Cullen, G. E., Studies of acidosis. XIX. The colorimetric determination of hydrogen-ion concentration of blood plasma. J. Biol. Chem., 1922, 52, 501.

13. O'Leary, P. A., Greene, C. H., and Rowntree, L. G., Diseases of the liver; various types of syphilis of the liver with reference to tests for hepatic function. Arch. Int. Med., 1929, 44, 155.

14. Wintrobe, M. M., and Landsberg, J. W., A standardized technique for the blood sedimentation rate. Am. J. M. Sc., 1935, 189, 102.

15. Gibson, J. G., 2nd, and Evans, W. A., Jr., Climical studies of the blood volume. I. Clinical applications of a method employing the azo dye "Evans blue" and the spectrophotometer. J. Clin. Invest., 1930, 16, 301.

16. Bridges, M. A., and Mattice, N. R., Food and Beverage Analyses. Lea \& Febiger, Philadelphia, 1942, 2nd Ed.

17. Sherman, H. C., Chemistry of Food and Nutrition. Macmillan Co., New York, 1941.

18. Ricketts, W. E., Observations on portal cirrhosis with ascites. Ann. Int. Med., 1951, 34, 37.

19. Janeway, C. A., Gibson, S. T., Woodruff, L. M., Heyl, J. T., Bailey, O. T., and Newhouser, L. R., Chemical, clinical and immunological studies of the products of human plasma fractionation. VII. Concentrated human serum albumin. J. Clin. Invest., 1944, 23, 465.

20. Thorn, G. W., Armstrong, S. H., Jr., and Davenport, V. D., Chemical, clinical, and immunological studies on the products of human plasma fractionation. XXXI. The use of salt-poor concentrated human serum albumin solution in the treatment of hepatic cirrhosis. J. Clin. Invest., 1946, 25, 304.

21. Kunkel, H. G., Labby, D. D., Ahrens, E. H., Jr., Shank, R. E., and Hoagland, C. L., The use of concentrated human serum albumin in the treatment of cirrhosis of the liver. J. Clin. Invest., 1948, 27, 305.

22. Mankin, H., and Lowell, A., Osmotic factors influencing the formation of ascites in patients with cirrhosis of the liver. J. Clin. Invest., 1948, 27, 145.

23. Ralli, E. P., Robson, J. S., Clarke, D., and Hoagland, C. L., Factors influencing ascites in patients with cirrhosis of the liver. J. Clin. Invest., 1945, 24, 316. 